\title{
Prevalence of Drug Interaction in Severely Obese Individuals and Associated Factors: Baseline Results from a Clinical Trial
}

\author{
Ana Carolina Figueiredo Modesto $1, * \mathbb{C}$, Erika Aparecida Silveira ${ }^{1,2, * \mathbb{C}}$, \\ Ana Paula dos Santos Rodrigues 1,3(0), Dione Marçal Lima ${ }^{4}$, Mércia Pandolfo Provin ${ }^{4}$ \\ and Rita Goreti Amaral ${ }^{4}$ \\ 1 Post-Graduate Program in Health Sciences, School of Medicine, Federal University of Goiás, \\ Goiás 74605-050, Brazil; anapsr@gmail.com \\ 2 School of Medicine, Federal University of Goiás, Goiás 74605-050, Brazil \\ 3 Goiás Health Department, Goiás 74860-270, Brazil \\ 4 School of Pharmacy, Federal University of Goiás, Goiás 74605-170, Brazil; \\ dione.farmacia@gmail.com (D.M.L.); merciap@gmail.com (M.P.P.); ritagoreti26@gmail.com (R.G.A.) \\ * Correspondence: farmcarolina@gmail.com (A.C.F.M.); erikasil@terra.com.br (E.A.S.)
}

Received: 17 September 2020; Accepted: 9 October 2020; Published: 20 October 2020

\begin{abstract}
The prevalence of obesity is increasing worldwide and is commonly associated with comorbidities. The use of several drugs is often necessary, which leads to Potential Drug Interactions (PDI) that may increase the morbidity and mortality. This study aimed to analyze the prevalence of drug interaction and its association with socio-demographics, health status, and drug use in severely obese individuals. Baseline data from a randomized clinical trial registered at Clinicaltrial.gov (NCT02463435) were used. A total of 150 individuals aged 18-65 years with a body mass index of $35 \mathrm{~kg} / \mathrm{m}^{2}$ were included. The outcome variable was the presence of PDI, and the explanatory variables were divided into the following four levels: socio-demographic, lifestyle, health, and medication use. The prevalence of PDI was 50\% $(n=75)(95 \%$ CI $41-58)$. The variables associated with drug-drug interactions in the multiple analyses were arterial hypertension (PR 1.83, 95\%, CI 1.10-3.04), polypharmacy (PR 3.12, 95\%, CI 2.17-4.50), and diabetes mellitus (PR 0.60, 95\%, CI 0.45-0.81). The risk factors for the occurrence of drug interaction were the presence of diabetes mellitus, hypertension, and polypharmacy.
\end{abstract}

Keywords: severe obesity; drug interaction; drug utilization reviews; randomized controlled trial; pharmacoepidemiology

\section{Introduction}

The prevalence of obesity has increased over the years, in particular of severe obesity. The category of obesity with body mass index $(\mathrm{BMI}) \geq 35 \mathrm{~kg} / \mathrm{m}^{2}$ [1] presented the highest increase among other categories such as overweightness and obesity [2] and was recorded in $12 \%$ of the world population in 2015 [3]. Obesity culminates with the emergence of other comorbidities [4], such as the already well-established triad of arterial hypertension (AH) [5], diabetes mellitus (DM) [6], and hypercholesterolemia [7]. In addition, these patients may still have problems related to the renal system [8], hepatic system [9], skeletal muscle [10], and respiratory system, among others [11]. In general, this leads to a decline in an individual's health, as well as an increase in expenses and consequent overloading of health systems [12,13].

Drugs are the main therapeutic tools used for the control and treatment of these morbidities $[14,15]$. However, if misused, these drugs can adversely affect the patients [16] and they have been involved 
in many death-related incidents arising from monitoring failures, omissions to provide necessary treatments, and potential drug interactions (PDI), among others [16,17]. PDI are responsible for therapeutic failures and constitute a safety problem as they are responsible for most of the incidents related to drug use [18]. For this reason, the World Health Organization urged its signatories to join efforts to reduce deaths associated with drug misuse by 2022 [19].

Considering the importance of PDI in drug-related morbidity and mortality [20], the prevalence and risk factors for its occurrence in groups of patients with acquired immunodeficiency syndrome [21], elderly [22], and oncology [23] is well-established. However, in the obese population, especially among the severely obese, such parameters are not yet known. Pharmacoepidemiological studies involving this group of patients are more related to elucidating pharmacological aspects of obesity treatment as well as new molecules and therapeutic targets $[24,25]$. A study designed to estimate the prevalence of obesity and associated morbidities described the use of anti-hypertensives and lipid lowering drugs, but did not consider other concomitant medications [26].

Given the knowledge gap, identification and consideration of the importance of obesity as a public health problem as well as the prioritization of medication safety in world agenda is important. This study aimed to analyze the prevalence of PDI and associated factors in severely obese patients.

\section{Materials and Methods}

\subsection{Setting and Study Design}

This study is a cross-sectional analysis of baseline data from the DieTBra Trial (Effect of Nutritional intervention and Olive Oil in Severe Obesity: Randomized Controlled Trial) with the following primary objective: to evaluate the effects of a nutritional treatment on inflammation, weight loss, and biochemical markers in severely obese individuals with a record in ClinicalTrials.gov, NCT02463435. In the trial protocol, all drug use variables and analyses were pre-specified in the baseline data. Patients were referred from the Brazilian Unified Health System (UHS) of primary healthcare to the nutrition and severe obesity outpatient clinic in a large university hospital in the Central-West region of Brazil. Excluded from the study were individuals that had already undergone bariatric surgery, were under actual nutritional treatment for weight loss or who in the previous two years used antiobesity drugs, had HIV/AIDS, had a heart/kidney/hepatic insufficiency, had a chronic obstructive pulmonary disease, cancer, or were pregnant. Further methodological details can be found in the DieTBra Trial articles with baseline data published elsewhere [27,28]. Data were collected from June 2015 to February 2016. All the participants gave their written consent to participate in this study, thereby conforming to the Helsinki declaration. This study was approved by Hospital of Clinics of Goiás Federal University research ethics committee with the registration number 1.545 .504 in 08/14/2014.

\subsection{Subjects}

The subjects in the study included individuals aged 18 to 65 years with BMI $\geq 35 \mathrm{~kg} / \mathrm{m}^{2}$ referenced from primary care to the outpatient clinic specializing in the care of severely obese patients. Individuals residing outside the metropolitan area; who had already undergone bariatric surgery in the last three months which reduced more than $8 \%$ of their weight; who had received treatment in the same outpatient clinic; and those currently being treated for obesity, pregnant women, infants and those with special needs were excluded. Figure 1 shows the flow diagram of the enrolment of study patients.

\subsection{Variables}

The outcome variable was the presence of PDI. Firstly, the Micromedex ${ }^{\circledR}$ database was searched for all the drugs used by the patients to identify PDI. Then, a reclassification of PDI was made as present, when at least one PDI was identified, and absent, when no PDI was identified. The PDIs were classified into four categories according to the severity: namely, contraindicated, major, moderate, and minor according to the Micromedex ${ }^{\circledR}$ categories [29]. The contraindicated category included conditions 
where drugs are contraindicated for concomitant use. The major category included conditions where the interaction may be life-threatening and/or require medical intervention to decrease or avoid serious adverse effects. The moderate category was defined as the condition in which the interaction may result in an exacerbation of the patient's health problem and/or require a change in treatment. The minor category included cases wherein the interaction would result in limited clinical effects, and where the manifestations may include an increased severity of side effects but do not demand a major change in treatment [29].

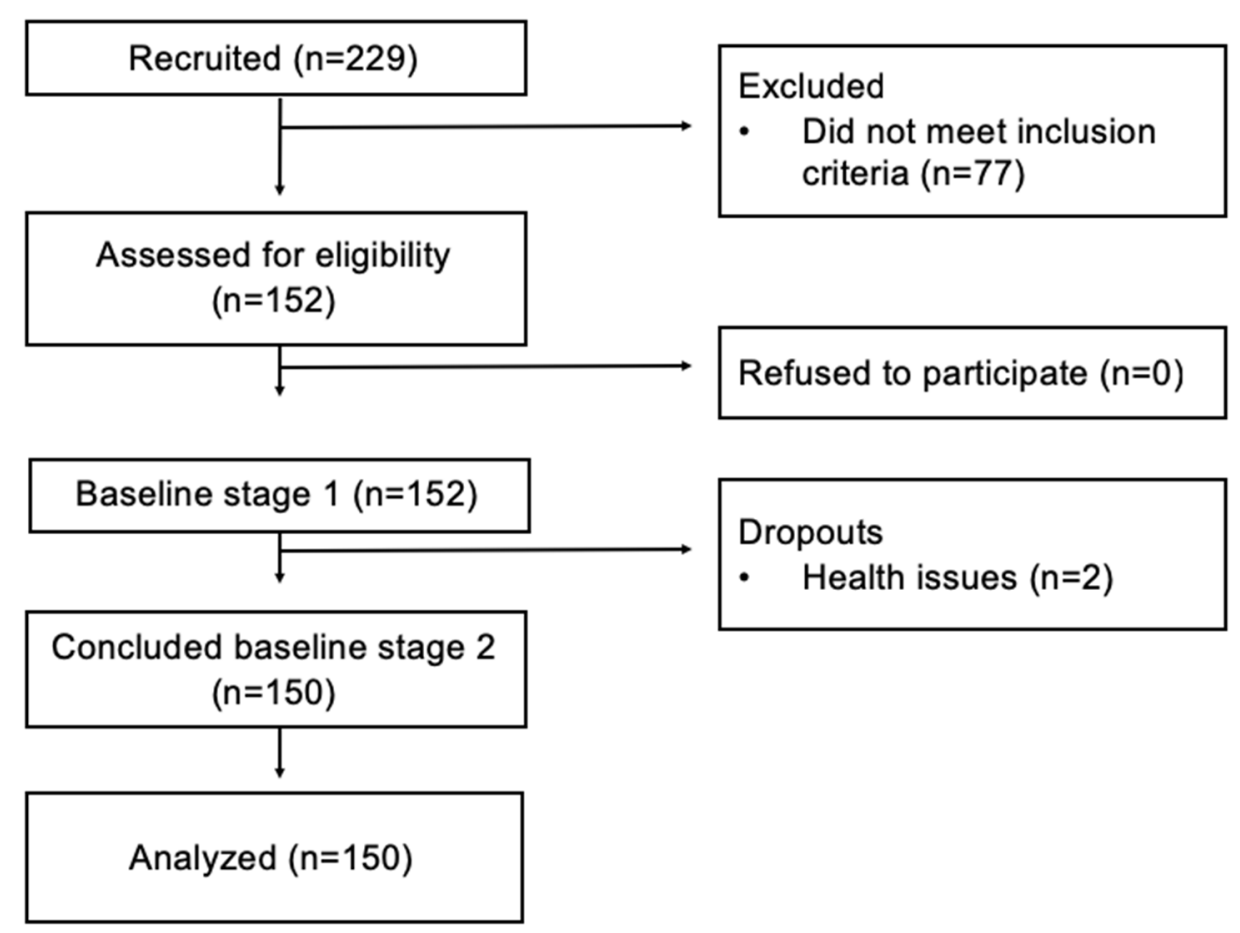

Figure 1. Flow diagram of the study patients' enrollment.

The explanatory variables were divided into four levels: socio-demographic, lifestyle, health, and drug use.

Socio-demographic: sex, age, years of study, skin color, living with partner, and economic class according to Brazil's standard economic classification criteria [30].

Lifestyle: the consumption of alcoholic beverages was estimated by questioning the patient about the amount of alcohol consumed the previous week [31]. Smoking was categorized under "non-smoker", "ex-smoker," and "smoker" [32].

Health: body mass index (BMI) was calculated by dividing the body weight into $\mathrm{kg}$ and height in meters squared. Patients with BMI $\geq 35 \mathrm{~kg} / \mathrm{m}^{2}$ and BMI $\geq 40 \mathrm{~kg} / \mathrm{m}^{2}$ were classified as having grade II obesity and grade III obesity, respectively [33]. AH was classified by blood pressure levels higher than 140/90 mm/Hg [34] and the use of antihypertensive drugs. DM was classified by fasting plasma glucose values $\geq 126 \mathrm{mg} / \mathrm{dL}$ [35] and the use of anti-diabetic drugs. Hypercholesterolemia was classified by the presence of one or more of the following conditions: isolated hypercholesterolemia, isolated hypertriglyceridemia, mixed hyperlipidaemia or low-density lipoprotein [36], and the use of anti-lipemic drugs. The number of self-reported morbidities [33] consisted of the number of diseases reported by the patient at the interview time. 
Drug use: the use of drugs that cause weight gain [24,37-39] and polypharmacy, which is the practice of using five or more drugs [40], were categorized as "yes" and "no". The practice of self-medication [41] was assessed using the question: "Do you have a prescription?" for each drug used by the patient and the answer was classified as "yes" or "no" according to the patient's habit of using non-prescription drugs. The drugs used by the patient were classified according to the Anatomical Therapeutic and Chemical Classification (ATC) [42]. Associations of drugs not found on the ATC classification and phytotherapeutic drugs were categorized as non-classifiable (NC).

\subsection{Data Collection}

Patients enrolled in the study were interviewed by members of the research team who were appropriately trained to collect the socio-demographic data. Data regarding drug therapy were obtained by a pharmacist on the research team. Anthropometric data and health status were collected by a nutritionist on the research team. All members of the research team were trained according to standard operating procedures of the clinical trial.

\subsection{Statistical Analyses}

The association of variables was tested using the Pearson's Chi-square test, Fisher's exact test, or square Chi test for a linear trend, with a significance level of $5 \%$. Variables with a $p$-value of 0.20 in the bivariate analysis were included in a Poisson regression model. The measure of association between the variables was the prevalence ratio (PR), with a confidence interval (CI) of 95\%. STATA software, version 14 was used for the analyses. Data were processed with double input and any inconsistencies were corrected promptly.

\section{Results}

150 patients were analyzed and the PDI prevalence was 50\% $(n=75)(95 \%$ CI $41-58)$. Each patient had on average $1.54 \mathrm{PDI}(\mathrm{SD} \pm 0.20,95 \%$ CI $1.13-1.05)$. Approximately $84 \%(n=63)$ of PDI were due to the use of non-prescription drugs. A total of 236 pairs of drugs with PDI were analyzed. Regarding the severity of potential drug interactions, most $98.72 \%(n=233)$ were contraindicated, major and moderate. Among these, the most frequent pairs were ethinylestradiol + caffeine and diclofenac + losartan, with $93.0 \%(n=14)$ and e $5.08 \%(n=12)$, respectively. The only contraindicated association observed was between trometamol ketorolac + naproxen $(0.42 \%)$. Among the major cases, the association with diclofenac + hydrochlorothiazide was the most prevalent, with $10.53 \%$. Among the associations considered as less severe, $10.22 \%(n=14)$ occurred with ethinylestradiol + caffeine, and $8.76 \%(n=12)$ with diclofenac + losartan (Table 1$)$.

There was no association between PDI and socio-demographic variables and lifestyle (Table 2). A statistically significant association was observed between the health and medication use variables and the occurrence of PDI with hypertension, diabetes, number of self-reported morbidities, use of drugs that cause weight gain, and polypharmacy (Table 3). After the multiple analyses by Poisson regression, the variables that remained associated with the occurrence of PDI were hypertension (PR 1.83, 95\% CI 1.10-3.04), polypharmacy (PR 3.12, 95\% CI 2.17-4.50), and diabetes (PR 0.60, 95\% CI 0.45-0.81) (Table 4).

The therapeutic classes most associated with occurrence of PDI were alimentary tract and metabolism $(p<0.001)$, blood and blood forming organs $(p=0.005)$, cardiovascular system $(p<0.001)$, systemic hormonal preparations, excluding sex hormones and insulin $(p=0.001)$, and musculoskeletal system $(p<0.001)$ (Table 5). 
Table 1. Potential drug interactions more prevalent in adults with severe obesity according to severity and clinical management.

\begin{tabular}{|c|c|c|c|c|}
\hline Severity & $n$ & $\%$ & $\begin{array}{l}\text { More Prevalent Pairs of } \\
\text { Drugs with Potential Drug } \\
\text { Interactions }\end{array}$ & Management * \\
\hline Contra-indicated & 1 & $0.42 \%$ & $\begin{array}{c}\text { Trometamol cetrolac + } \\
\text { Naproxen }\end{array}$ & $\begin{array}{l}\text { Concurrent use may cause in enhanced gastrointestinal } \\
\text { adverse effects (peptic ulcers, gastrointestinal bleeding } \\
\text { and/or perforation. }\end{array}$ \\
\hline \multirow{5}{*}{ Major } & \multirow{5}{*}{95} & \multirow{5}{*}{$40.25 \%$} & $\begin{array}{c}\text { Diclofenac }+ \\
\text { Hydrochlorothiazide }\end{array}$ & $\begin{array}{l}\text { Concurrent use may result in impaired renal function. } \\
\text { When co-administration is required, monitor renal } \\
\text { function at the beginning and during treatment, as well } \\
\text { as blood pressure control. }\end{array}$ \\
\hline & & & $\begin{array}{l}\text { Acetylsalicylic acid + } \\
\text { Metformin }\end{array}$ & $\begin{array}{l}\text { Concomitant use may cause hypoglycemia. A more } \\
\text { frequent monitoring of blood glucose is suggested. } \\
\text { Advise patients to recognize early signs and symptoms } \\
\text { of hypoglycemia. }\end{array}$ \\
\hline & & & $\begin{array}{c}\text { Diclofenac }+ \text { Acetylsalicylic } \\
\text { acid }\end{array}$ & $\begin{array}{l}\text { Concurrent use may result in impaired renal function. } \\
\text { When co-administration is required, monitor renal } \\
\text { function at the beginning and during treatment, as well } \\
\text { as blood pressure control. }\end{array}$ \\
\hline & & & Diclofenac + Fluoxetine & $\begin{array}{l}\text { Concurrent use results in an increased risk of bleeding. } \\
\text { Monitoring the patient for signs and symptoms of } \\
\text { bleeding may be necessary. }\end{array}$ \\
\hline & & & $\begin{array}{l}\text { Hydrochlorothiazide }+ \\
\text { Acetylsalicylic acid }\end{array}$ & $\begin{array}{l}\text { Concurrent use may result in impaired renal function. } \\
\text { When co-administration is required, monitor renal } \\
\text { function at the beginning and during treatment, as well } \\
\text { as blood pressure control. }\end{array}$ \\
\hline \multirow{9}{*}{ Moderate } & \multirow{9}{*}{137} & \multirow{9}{*}{$58.05 \%$} & Ethinylestradiol + Caffeine & $\begin{array}{l}\text { Concurrent use may cause central nervous stimulation } \\
\text { and insomnia. Advise patients to decrease caffeine } \\
\text { intake while using contraceptives. } \\
\text { Concurrent use may result in impaired renal function. } \\
\text { When co-administration is required, monitor renal } \\
\text { function at the beginning and during treatment, as well } \\
\text { as blood pressure control. }\end{array}$ \\
\hline & & & $\begin{array}{l}\text { Hydrochlorothiazide + } \\
\text { Enalapril }\end{array}$ & $\begin{array}{l}\text { Concurrent use may result in an excessive increase in } \\
\text { blood pressure reduction. At the beginning of therapy, it } \\
\text { may be necessary to decrease diuretic dose or increase } \\
\text { salt intake. If such measures are not effective, reduce the } \\
\text { initial dose of Enalapril. }\end{array}$ \\
\hline & & & $\begin{array}{l}\text { Hydrochlorothiazide + } \\
\text { Propranolol }\end{array}$ & $\begin{array}{l}\text { Concurrent use may cause changes in patient's glycemic } \\
\text { and lipid profile. Monitoring of such parameters } \\
\text { is suggested. }\end{array}$ \\
\hline & & & Enalapril + Metformin & $\begin{array}{l}\text { Concomitant use may cause hypoglycemia. A more } \\
\text { frequent monitoring of blood glucose is suggested. } \\
\text { Advise patients to recognize early signs and symptoms } \\
\text { of hypoglycemia. }\end{array}$ \\
\hline & & & Captopril + Metformin & $\begin{array}{l}\text { Concomitant use may cause hypoglycemia. A more } \\
\text { frequent monitoring of blood glucose is suggested. } \\
\text { Advise patients to recognize early signs and symptoms } \\
\text { of hypoglycemia. }\end{array}$ \\
\hline & & & $\begin{array}{l}\text { Hydrochlorothiazide + } \\
\text { Salbutamol }\end{array}$ & $\begin{array}{l}\text { Concurrent use may increase the risk of hypokalemia as } \\
\text { well as changes in electrocardiogram. Monitoring of } \\
\text { potassium levels as well as cardiac function } \\
\text { is recommended. }\end{array}$ \\
\hline & & & Diclofenac + Captopril & $\begin{array}{l}\text { Concurrent use may result in impaired renal function. } \\
\text { When co-administration is required, monitor renal } \\
\text { function at the beginning and during treatment, as well } \\
\text { as blood pressure control. }\end{array}$ \\
\hline & & & $\begin{array}{l}\text { Hydrochlorothiazide }+ \\
\text { Captopril }\end{array}$ & $\begin{array}{l}\text { Concurrent use may result in an excessive increase in } \\
\text { blood pressure reduction. At the beginning of therapy, it } \\
\text { may be necessary to decrease diuretic dose or increase } \\
\text { salt intake. If such measures are not effective, reduce the } \\
\text { initial dose of Captopril. }\end{array}$ \\
\hline & & & $\begin{array}{l}\text { Levothyroxine + } \\
\text { Omeprazole }\end{array}$ & $\begin{array}{l}\text { Concurrent use may compromise the efficacy of } \\
\text { Levothyroxine. Advise patient to use Levothyroxine } \\
\text { four hours before or after omeprazole. Monitoring of } \\
\text { TSH levels is suggested. }\end{array}$ \\
\hline
\end{tabular}

${ }^{1}$ : One patient could have more than a pair of drug interactions. ${ }^{2}$ : The remaining $1.72 \%$ are related to potential drug interactions without clinical relevance. ${ }^{*}$ Truven Health Analytics. Micromedex. 2017 [29]. 
Table 2. Prevalence of Potential Drug Interactions (PDI) and its association with sociodemographic and lifestyle variables in adults with severe obesity $(n=150)$.

\begin{tabular}{|c|c|c|c|c|}
\hline Variables & $n(\%)$ & PDI Presence & PR (CI 95\%) & $p$ Value \\
\hline \multicolumn{5}{|c|}{ Sex } \\
\hline Female & $128(85.33)$ & $63(49.22)$ & 1.00 & 0.644 * \\
\hline Male & $22(14.67)$ & $12(54.55)$ & $0.90(0.59-1.37)$ & \\
\hline \multicolumn{5}{|c|}{ Age } \\
\hline $18-39$ & $76(50.67)$ & $34(44.74)$ & 1.00 & 0.139 ** \\
\hline $40-49$ & $53(35.33)$ & $28(52.83)$ & $1.18(0.82-1.68)$ & \\
\hline$\geq 50$ & $21(14.00)$ & $13(61.90)$ & $1.38(0.90-2.10)$ & \\
\hline \multicolumn{5}{|c|}{ Years of study } \\
\hline$<10$ years & $75(50.00)$ & $36(48.00)$ & 1.00 & 0.624 * \\
\hline$>10$ years & $75(50.00)$ & $39(52.00)$ & $1.08(0.78-1.49)$ & \\
\hline \multicolumn{5}{|c|}{ Skin color } \\
\hline White & $46(30.67)$ & $21(45.65)$ & 1.00 & 0.530 ** \\
\hline Brown & $83(55.33)$ & $43(51.81)$ & $1.13(0.77-1.65)$ & \\
\hline Black & $21(14.00)$ & $11(52.38)$ & $1.14(0.68-1.92)$ & \\
\hline \multicolumn{5}{|c|}{ Economic class } \\
\hline Class A/B & $34(22.67)$ & $18(52.94)$ & $1.13(0.76-1.66)$ & 0.556 * \\
\hline Class C & $92(61.33)$ & $43(46.74)$ & 1.00 & \\
\hline Class D/E & $24(16.00)$ & $14(58.33)$ & $1.24(0.83-1.86)$ & \\
\hline \multicolumn{5}{|c|}{ Lives with partner } \\
\hline Yes & $55(36.67)$ & $28(50.91)$ & $1.02(0.73-143)$ & 0.865 * \\
\hline No & $95(63.33)$ & $47(49.47)$ & 1.00 & \\
\hline \multicolumn{5}{|c|}{ Smoking } \\
\hline Non-smoker & $101(67.33)$ & $48(47.52)$ & 1.00 & 0.384 * \\
\hline Smoker/Ex-smoker & $49(32.67)$ & $27(55.10)$ & $1.15(0.83-1.60)$ & \\
\hline \multicolumn{5}{|c|}{ Alcohol intake ${ }^{1}$} \\
\hline No & $13(15.48)$ & $5(38.46)$ & 1.00 & $0.318^{*}$ \\
\hline Yes & $71(84.52)$ & $38(53.52)$ & $1.39(0.67-2.87)$ & \\
\hline
\end{tabular}

Table 3. Prevalence of Potential Drug Interactions and its association with health profile and drug use variables in adults with severe obesity $(n=150)$.

\begin{tabular}{|c|c|c|c|c|}
\hline Variables & $n(\%)$ & PDI Presence & PR (CI 95\%) & $p$ Value * \\
\hline \multicolumn{5}{|c|}{ Body Mass Index } \\
\hline $35-39$ & $27(18.00)$ & $13(48.15)$ & 1.00 & \multirow[t]{2}{*}{0.832} \\
\hline$\geq 40$ & $123(82.00)$ & $62(50.41)$ & $1.04(0.68-1.60)$ & \\
\hline \multicolumn{5}{|c|}{ Arterial Hypertension } \\
\hline No & $65(43.33)$ & $15(23.08)$ & 1.00 & \multirow[t]{2}{*}{$<0.001$} \\
\hline Yes & $85(56.67)$ & 60 (70.59) & $3.05(1.91-4.87)$ & \\
\hline \multicolumn{5}{|l|}{ Diabetes } \\
\hline No & $90(60.00)$ & $38(42.22)$ & 1.00 & \multirow[t]{2}{*}{0.020} \\
\hline Yes & $60(40.00)$ & $37(61.67)$ & $1.46(1.06-2.00)$ & \\
\hline \multicolumn{5}{|c|}{ Hypercholesterolemia } \\
\hline No & $94(62.67)$ & $45(47.87)$ & 1.00 & \multirow[t]{2}{*}{0.500} \\
\hline Yes & $56(37.33)$ & $30(53.57)$ & $1.11(0.80-1.54)$ & \\
\hline \multicolumn{5}{|c|}{ Self-reported morbidities } \\
\hline$\leq 3$ & $89(59.33)$ & $30(33.71)$ & 1.00 & \multirow[t]{2}{*}{$<0.001$} \\
\hline$\geq 4$ & $61(40.67)$ & 45 (73.77) & $2.18(1.57-3.03)$ & \\
\hline \multicolumn{5}{|c|}{ Drugs that cause weight gain } \\
\hline No & $106(70.67)$ & $42(39.62)$ & 1.00 & \multirow[b]{2}{*}{$<0.001$} \\
\hline Yes & $44(29.33)$ & $33(75.00)$ & $1.89(1.41-2.53)$ & \\
\hline \multicolumn{5}{|c|}{ Self-medication } \\
\hline 0 & $23(15.33)$ & $12(52.17)$ & $1.13(0.72-1.78)$ & \multirow{3}{*}{0.463} \\
\hline $1-2$ & $89(59.33)$ & $41(46.07)$ & 1.00 & \\
\hline$\geq 3$ & $38(25.33)$ & $22(57.89)$ & $1.25(0.88-1.78)$ & \\
\hline \multicolumn{5}{|c|}{ Polypharmacy } \\
\hline No & $101(67.33)$ & $29(28.71)$ & 1.00 & \multirow[t]{2}{*}{$<0.001$} \\
\hline Yes & $49(32.67)$ & $46(93.88)$ & $3.26(2.38-4.48)$ & \\
\hline
\end{tabular}

* Pearson's Chi-square. 
Table 4. Multivariate analysis by Poisson Regression.

\begin{tabular}{|c|c|c|c|}
\hline Variables & Adjusted Prevalence Ratio & Adjusted CI 95\% & $p$ Value * \\
\hline \multicolumn{4}{|c|}{ Arterial Hypertension } \\
\hline No & 1 & & \\
\hline Yes & 1.82 & $1.10-3.04$ & 0.020 \\
\hline \multicolumn{4}{|c|}{ Diabetes } \\
\hline No & 1 & & \\
\hline Yes & 0.60 & $0.45-0.81$ & 0.001 \\
\hline \multicolumn{4}{|c|}{ Drugs that cause weight gain } \\
\hline No & 1 & & \\
\hline Yes & 1.35 & $0.99-1.84$ & 0.059 \\
\hline \multicolumn{4}{|c|}{ Polypharmacy } \\
\hline No & 1 & & \\
\hline Yes & 3.12 & $2.17-4.50$ & $<0.001$ \\
\hline
\end{tabular}

Table 5. Prevalence of drugs involved in Potential Drug Interactions distributed by Anatomical Therapeutic and Chemical Classification (ATC) in adults with severe obesity $(n=150)$.

\begin{tabular}{|c|c|c|c|c|}
\hline & ATC Classification & $n(\%)$ & PDI Presence & $p$ Value \\
\hline A & Alimentary Tract and metabolism & $57(38.00 \%)$ & $39(68.42 \%)$ & $<0.001 *$ \\
\hline $\mathrm{B}$ & Blood and forming blood organs & $11(7.33 \%)$ & $10(90.91 \%)$ & $0.005^{* *}$ \\
\hline $\mathrm{C}$ & Cardiovascular system & $65(43.33 \%)$ & $48(73.85 \%)$ & $<0.001 *$ \\
\hline $\mathrm{D}$ & Dermatologicals & 0 & 0 & - \\
\hline G & Genito urinary system and sex hormones & $12(8.00 \%)$ & $7(58.33 \%)$ & $0.547 *$ \\
\hline $\mathrm{H}$ & $\begin{array}{l}\text { Systemic hormonal preparations, excluding sex } \\
\text { hormones and insulins }\end{array}$ & $10(6.67 \%)$ & $10(100 \%)$ & $0.001^{* *}$ \\
\hline $\mathrm{J}$ & Antiinfectives for systemic use & $6(4.00 \%)$ & $4(66.67 \%)$ & $0.341 * *$ \\
\hline $\mathrm{L}$ & Antineoplasic and immunomodulating agents & 0 & 0 & - \\
\hline $\mathrm{M}$ & Musculo-skeletal system & $97(64.67 \%)$ & $60(61.86 \%)$ & $<0.001 *$ \\
\hline $\mathrm{N}$ & Nervous system & $86(57.33 \%)$ & $44(51.16 \%)$ & $0.741 *$ \\
\hline $\mathrm{P}$ & Antiparasitic products, insecticides and repellents & $1(0.67 \%)$ & $0(0.00 \%)$ & - \\
\hline $\mathrm{R}$ & Respiratory system & $17(11.33 \%)$ & $10(58.82 \%)$ & $0.440 *$ \\
\hline $\mathrm{S}$ & Sensory organs & $1(0.67 \%)$ & $0(0.00 \%)$ & - \\
\hline $\mathrm{V}$ & Various & 0 & 0 & - \\
\hline $\mathrm{NC}$ & Non-Classifiable & $16(10.67 \%)$ & $10(62.50 \%)$ & 0.290 * \\
\hline
\end{tabular}

\section{Discussion}

According to the literature, this is the first study to evaluate the drug use profile in severely obese patients associated with the occurrence of PDI and other variables on health conditions. It is increasingly relevant to know the health aspects and risks in severe obesity, since obesity is the fastest growing health condition in the world [1], and the one of greatest risk of aggravations and consequent mortality. The presence of PDI was elevated among the severely obese in association with other morbidities such as diabetes and hypertension, in addition to polypharmacy. Obesity and the morbidities associated with obesity, such as hypertension and diabetes [6], demand the use of more drugs, leading the patient to polypharmacy, which further increases the likelihood of occurrence of PDI. Our study demonstrated that polypharmacy increased the risk of the severely obese patient presenting PDI more than three-fold.

Although previous studies related to the prevalence of PDI in severely obese individuals are not available, such outcomes have been described in studies on patients with chronic health conditions [22,23]. The prevalence of PDI in the present study was higher than observed in a study with the elderly (36.9\%) [22], and less than in onco-haematological patients (71.3\%) [23]. This variability in prevalence may occur due to differences between patient/morbidity, study sites, and countries [43]. 
These findings reinforce the need for further studies regarding drug use in the severely obese, to establish the patterns of use and therapeutic classes more associated with PDI and their clinical relevance.

In our study, the association with AH and PDI was observed. A clinical explanation for this result may be the difficulty of pharmacological control of AH monotherapy in obese individuals [5]. The achievement of satisfactory blood pressure levels is a problem in clinical practice in obese patients due to the increased activity of the renin-angiotensin system and aldosterone, which decreases the efficacy of pharmacological treatment [5]. The addition of multiple drugs may be necessary to achieve appropriate blood pressure levels in these patients [3], which leads to an increased risk of developing PDI.

As in $\mathrm{AH}, \mathrm{DM}$ treatment is also commonly performed with drug associations [44], partially explaining the observed association between PDI and DM. Although the pathophysiology associated with refractoriness to pharmacological treatment of DM in the severely obese is still unknown, in some cases, it may be caused by impaired pharmacokinetics and the bioavailability of drugs because of changes in the volume of distribution [45], the liver [9], and renal function [46]. It is suggested that adequate glycemic control may not be achieved due to the exposure of sub-therapeutic doses, which leads to the addition of other drugs to the therapeutic regimen [44], which, consequently, increases the possibility of the occurrence of PDI.

Polypharmacy is a reality among patients with chronic conditions [47]. Although necessary, polypharmacy should be done with caution, since it is associated with the occurrence of PDI, as observed in the present study and described in previous studies [48]. It is known that PDI may be associated with the occurrence of adverse drug reactions [49], as well as increased hospitalization time [20]. Although no other research was found addressing polypharmacy and the prevalence of PDI in obese patients, this study's results are in line with other studies in patients with chronic diseases [21-23]. In obese patients, these complications may have more serious consequences, such as the onset of serious adverse reactions and a difficulty in controlling comorbidities.

Although sociodemographic variables have not demonstrated an association with the occurrence of PDI, these results are in line with those of other studies. Sex and age were not associated with the occurrence of PDI in a study conducted in onco-hematological patients [23] and the institutionalized elderly, as well as the marital status and schooling in the latter case [43]. The occurrence of PDI in obese individuals seems to be more associated with clinical aspects and morbidities than sociodemographic variables.

The drugs that act in the digestive system and metabolism were associated with the occurrence of PDI, which may be partially explained by the presence of antidiabetics. These drugs' metabolism is made by the enzymatic systems involved in the metabolism of other drugs, which may result either in therapeutic ineffectiveness or in a safety problem [50].

The occurrence of PDI associated with cardiovascular and musculoskeletal system drugs may be partly explained by the influence of non-steroidal anti-inflammatory drugs on the action of antihypertensives. The result of such PDI is already well described in the literature, and it decreases the effects of antihypertensives to control patients' blood pressure levels [51,52]. Since obese patients commonly suffer from back, knee, and ankle pain, among others [10], therapy with nonsteroidal anti-inflammatory drugs may be necessary [53]. This is a PDI of clinical importance due to its potential for patient harm. There is evidence suggesting the raise of serum creatinine in patients in the use of NSAIDS [52] and this is a parameter that must be monitored during concomitant therapy. The raise of serum creatinine may lead to renal failure and consequently may affect blood pressure control [51]. This is a relevant aspect, especially in the severely obese, because it increases the risk of cardiovascular events [36]. Healthcare professionals must be aware of the risk and its clinical management to identify the reduction of $\mathrm{AH}$ treatment effectiveness.

As a possible limitation of this research we could mention the number of patients and their conduction in a single center. However, we emphasize that the results are consistent and relevant to the field of obesity, especially of the severe obese, with a few studies. Although drug use variables and 
their statistical analysis were not detailed in the clinical trial protocol, all details on this topic were part of a specific objective of original study and were pre-specified in the protocol approved by the local ethics committee. We highlight that all requirements for good clinical research practices were met and strict quality control criteria and methodological rigor were followed in all stages of the research. This study has great importance for clinical practice, as it is the first to analyze the occurrence of PDI and associated factors in severely obese patients. PDI are a major problem among individuals with severe obesity due to their high prevalence and association with other morbidities. However, PDI are susceptible to prevention and management if they are recognized and monitored, so knowing the factors associated with their occurrence has great importance for health professionals.

\section{Conclusions}

The presence of PDI in the present study was observed in 50\% of patients and associated with DM, $\mathrm{AH}$, and polypharmacy. Some drugs belonging to the first level of ATC classification have been shown to be associated with the onset of DIP: namely, alimentary tract and metabolism, blood and blood forming organs, cardiovascular system, systemic hormonal preparations, excluding sex hormones and insulins and the musculoskeletal system. Considering the PDI as a potential source of damage, especially in individuals with multimorbidities, such as the severely obese, a detailed review of the medications in use can prevent the manifestation of undesirable outcomes for the patient.

Author Contributions: Conceptualization, E.A.S. and R.G.A.; methodology, A.P.d.S.R., E.A.S., M.P.P., D.M.L., and R.G.A.; validation, A.P.d.S.R.; formal analysis, A.C.F.M., A.P.d.S.R., and M.P.P.; investigation, E.A.S. and A.P.d.S.R.; data curation, A.P.d.S.R. and E.A.S.; writing-original draft preparation, A.C.F.M. and A.P.d.S.R.; writing-review and editing, A.C.F.M., M.P.P., R.G.A., and D.M.L.; visualization, A.C.F.M.; supervision, E.A.S. and R.G.A.; project administration, E.A.S.; and funding acquisition, E.A.S. All authors have read and agreed to the published version of the manuscript.

Funding: This research was funded by Research Support Foundation of the State of Goiás (FAPEG), grant number 201310267000003.

Acknowledgments: We would like to thank all study participants and undergraduate volunteers who participated in our study and all at the Clinical Research Unit/UFG. We would also like to thank the Nutrition in Severe Obesity Outpatient Clinic (ANOG), the Clinical Hospital/UFG, and the Goiânia Municipal Health Secretariat. We thank all DieTBra Trial researchers for their effort to produce this high-quality research.

Conflicts of Interest: The authors declare no conflict of interest. The funders had no role in the design of the study; in the collection, analyses, or interpretation of data; in the writing of the manuscript, or in the decision to publish the results.

\section{References}

1. Di Cesare, M.; Bentham, J.; Stevens, G.A.; Rühli, F.J.; Staub, K.; Faeh, D.; Gutzwiller, F.; Al, E. NCD Risk Factor Collaboration (NCD-RisC) Trends in adult body-mass index in 200 countries from 1975 to 2014: A pooled analysis of 1698 population-based measurement studies with 19.2 million participants. Lancet 2016, 387, 1377-1396. [CrossRef]

2. Cheng, F.W.; Gao, X.; Mitchell, D.C.; Wood, C.; Still, C.D.; Rolston, D.; Jensen, G.L. Body mass index and all-cause mortality among older adults. Obesity 2016, 24, 2232-2239. [CrossRef] [PubMed]

3. Afshin, A.; Forouzanfar, M.H.; Reitsma, M.B.; Sur, P.; Estep, K.; Lee, A.; Marczak, L.; Mokdad, A.H.; Moradi-Lakeh, M.; Naghavi, M.; et al. Health Effects of Overweight and Obesity in 195 Countries over 25 Years. N. Engl. J. Med. 2017, 377, 13-27. [CrossRef] [PubMed]

4. Malta, D.C.; Silva Júnior, J.B. O Plano de Ações Estratégicas para o Enfrentamento das Doenças Crônicas Não Transmissíveis no Brasil e a definição das metas globais para o enfrentamento dessas doenças até 2025: Uma revisão. Epidemiol. Serviços Saúde 2013, 22, 151-164. [CrossRef]

5. Cohen, J.B. Hypertension in Obesity and the Impact of Weight Loss. Curr. Cardiol. Rep. 2017, 19, 1-8. [CrossRef]

6. Bae, J.; Lage, M.; Mo, D.; Nelson, D.R.; Hoogwerf, B. Obesity and glycemic control in patients with diabetes mellitus: Analysis of physician electronic health records in the US from 2009-2011. J. Diabetes Complicat. 2016, 30, 212-220. [CrossRef] 
7. Allam-Ndoul, B.; Guénard, F.; Garneau, V.; Cormier, H.; Barbier, O.; Pérusse, L.; Vohl, M.-C. Association between Metabolite Profiles, Metabolic Syndrome and Obesity Status. Nutrients 2016, 8, 324. [CrossRef]

8. Vitolo, E.; Santini, E.; Salvati, A.; Volterrani, D.; Duce, V.; Bruno, R.; Solini, A. Metabolic and Hormonal Determinants of Glomerular Filtration Rate and Renal Hemodynamics in Severely Obese Individuals. Obes. Facts 2016, 9, 310-320. [CrossRef]

9. Liew, P.-L.; Lee, W.-J.; Lee, Y.-C.; Wang, H.-H.; Wang, W.; Lin, Y.-C. Hepatic Histopathology of Morbid Obesity: Concurrence of Other Forms of Chronic Liver Disease. Obes. Surg. 2006, 16, 1584-1593. [CrossRef]

10. Calenzani, G.; Dos Santos, F.F.; Wittmer, V.L.; Freitas, G.K.F.; Paro, F.M. Prevalence of musculoskeletal symptoms in obese patients candidates for bariatric surgery and its impact on health related quality of life. Arch. Endocrinol. Metab. 2017, 61, 319-325. [CrossRef]

11. Stenholm, S.; Head, J.; Aalto, V.; Kivimäki, M.; Kawachi, I.; Zins, M.; Goldberg, M.; Platts, L.G.; Zaninotto, P.; Hanson, L.L.M.; et al. Body mass index as a predictor of healthy and disease-free life expectancy between ages 50 and 75: A multicohort study. Int. J. Obes. 2017, 41, 769-775. [CrossRef] [PubMed]

12. Sonntag, D.; Jarczok, M.N.; Ali, S. DC-Obesity: A New Model for Estimating Differential Lifetime Costs of Overweight and Obesity by Socioeconomic Status. Obesity 2017, 25, 1603-1609. [CrossRef] [PubMed]

13. Laxy, M.; Stark, R.G.; Peters, A.; Hauner, H.; Holle, R.; Teuner, C.M. The Non-Linear Relationship between BMI and Health Care Costs and the Resulting Cost Fraction Attributable to Obesity. Int. J. Environ. Res. Public Health 2017, 14, 984. [CrossRef] [PubMed]

14. Gazmararian, J.A.; Frisvold, D.; Zhang, K.; Koplan, J.P. Obesity is associated with an increase in pharmaceutical expenses among university employees. J. Obes. 2015, 2015, 7. [CrossRef]

15. Narbro, K.; Agren, G.; Jonsson, E.; Näslund, I.; Sjöström, L.; Peltonen, M. Swedish Obese Subjects Intervention Study Pharmaceutical Costs in Obese Individuals. Arch. Intern. Med. 2002, 162, 2061-2069. [CrossRef] [PubMed]

16. Ferner, R.E.; Easton, C.; Cox, A.R. Deaths from Medicines: A Systematic Analysis of Coroners' Reports to Prevent Future Deaths. Drug Saf. 2018, 42, 445-451. [CrossRef]

17. Ferner, R.E. The epidemiology of medication errors: The methodological difficulties. Br. J. Clin. Pharmacol. 2009, 67, 614-620. [CrossRef]

18. Gosho, M.; Maruo, K.; Tada, K.; Hirakawa, A. Utilization of chi-square statistics for screening adverse drug-drug interactions in spontaneous reporting systems. Eur. J. Clin. Pharmacol. 2017, 3, 383-786. [CrossRef] [PubMed]

19. World Health Organization. Medication without Harm-Global Patient Safety Challenge on Medication Safety; World Health Organization: Geneva, Switzerland, 2017.

20. Souza, T.T.; de Godoy, R.R.; Rotta, I.; Pontarolo, R.; Fernandez-llimos, F.; Correr, C.J. Morbidade e mortalidade relacionadas a medicamentos no Brasil: Revisão sistemática de estudos observacionais. Rev. Ciênc. Farm Básica Appl. 2014, 35, 519-532.

21. Ramos, G.V.; Guaraldo, L.; Japiassu, A.M.; Bozza, F.A. Comparison of two databases to detect potential drug-drug interactions between prescriptions of HIV/AIDS patients in critical care. J. Clin. Pharm. Ther. 2015, 40, 63-67. [CrossRef] [PubMed]

22. Sönnerstam, E.; Sjölander, M.; Lövheim, H.; Gustafsson, M. Clinically relevant drug-drug interactions among elderly people with dementia. Eur. J. Clin. Pharmacol. 2018, 74, 1351-1360. [CrossRef] [PubMed]

23. Leger, D.Y.; Moreau, S.; Signol, N.; Fargeas, J.-B.; Picat, M.-A.; Penot, A.; Abraham, J.; Laroche, M.-L.; Bordessoule, D. Polypharmacy, potentially inappropriate medications and drug-drug interactions in geriatric patients with hematologic malignancy: Observational single-center study of 122 patients. J. Geriatr. Oncol. 2017, 9, 60-67. [CrossRef] [PubMed]

24. Apovian, C.M.; Aronne, L.J.; Bessesen, D.H.; McDonnell, M.E.; Murad, M.H.; Pagotto, U.; Ryan, D.H.; Still, C.D. Pharmacological Management of Obesity: An Endocrine Society Clinical Practice Guideline. J. Clin. Endocrinol. Metab. 2014, 100, 342-362. [CrossRef] [PubMed]

25. Narayanaswami, V.; Dwoskin, L.P. Obesity: Current and potential pharmacotherapeutics and targets. Pharmacol. Ther. 2017, 170, 116-147. [CrossRef] [PubMed]

26. Solmi, F.; Morris, S. Association between childhood obesity and use of regular medications in the UK: Longitudinal cohort study of children aged 5-11 years. BMJ Open 2015, 5, e007373. [CrossRef] [PubMed] 
27. Silveira, E.A.; Rosa, L.P.S.; Santos, A.S.A.C.; Cardoso, C.K.S. Type 2 Diabetes Mellitus in Class II and III Obesity: Prevalence, Associated Factors, and Correlation between Glycemic Parameters and Body Mass Index. Int. J. Environ. Res. Public Health 2020, 17, 3930. [CrossRef] [PubMed]

28. Santos, A.S.; Rodrigues, A.P.S.; Rosa, L.P.; Sarrafzadegan, N.; Silveira, E.A. Cardiometabolic risk factors and Framingham Risk Score in severely obese patients: Baseline data from DieTBra trial. Nutr. Metab. Cardiovasc. Dis. 2020, 30, 474-482. [CrossRef] [PubMed]

29. Truven Health Analytics. Micromedex; Truven Health Analytics: Greenwood Village, CO, USA, 2017. Available online: http://www.thomsonhc.com (accessed on 27 January 2017).

30. Abep. Critério Padrão de Classificação Econômica Brasil. Available online: http://www.abep.org/criteriobrasil (accessed on 27 January 2017).

31. Bloomfield, K.; Allamani, A.; Beck, F.; Bergmark, K.H.; Csemy, L.; Eisenbach-Stangl, I.; Elekes, Z.; Gmel, G.; Ker-Correa, F.; Knibbe, R.; et al. Gender, Culture and Alcohol Problems: A Multi-National Study; Project Final Report; Institute for Medical Informatics: Berlin, Germany, 2005.

32. Organizacíón Panamericana de la Salud. Guias Para el Control y Monitoreo de la Epidemia Tabaquica; Organizacíón Panamericana de la Salud: Caracas, Venezuela, 1995.

33. Obesity: Preventing and Managing the Global Epidemic; Report of a WHO Consultation; TRS 931; World Health Organization: Geneva, Switzerland, 2000.

34. Drozda, J.; Messer, J.V.; Spertus, J.; Abramowitz, B.; Alexander, K.; Beam, C.T.; Bonow, R.O.; Burkiewicz, J.S.; Crouch, M.; Goff, D.C.; et al. Performance Measures for Adults with Coronary Artery Disease and Hypertension: A Report of the American College of Cardiology Foundation/American Heart Association Task Force on Performance Measures and the American Medical Association. Circulation 2011, 124, 248-270.

35. American Diabetes Association. Standard of medical care in diabetes-2017. Diabetes Care 2017, 40 (Suppl. S1), s4-s128. [CrossRef]

36. National Cholesterol Education Program Expert Panel on Detection E and T of HBC in A. Third Report of the National Cholesterol Education Program (NCEP) Expert Panel on Detection, Evaluation, and Treatment of High Blood Cholesterol in Adults (Adult Treatment Panel III) final report. Circulation 2002, 106, 3143. [CrossRef]

37. Keith, S.W.; Redden, D.T.; Katzmarzyk, P.T.; Boggiano, M.M.; Hanlon, E.C.; Benca, R.M.; Ruden, D.; Pietrobelli, A.; Barger, J.L.; Fontaine, K.R.; et al. Putative contributors to the secular increase in obesity: Exploring the roads less traveled. Int. J. Obes. 2006, 30, 1585-1594. [CrossRef]

38. Apovian, C.M. Obesity: Definition, comorbidities, causes, and burden. Am. J. Manag. Care 2016, 22, s176-s185. [PubMed]

39. Domecq, J.P.; Prutsky, G.; Leppin, A.; Sonbol, M.B.; Altayar, O.; Undavalli, C.; Wang, Z.; Elraiyah, T.; Brito, J.P.; Mauck, K.F.; et al. Drugs Commonly Associated with Weight Change: A Systematic Review and Meta-analysis. J. Clin. Endocrinol. Metab. 2015, 100, 363-370. [CrossRef] [PubMed]

40. Guharoy, R. Polypharmacy: America's other drug problem. Am. J. Health Pharm. 2017, 74, 1305-1306. [CrossRef]

41. World Health Organization. The Role of the Pharmacist in Self-Care and Self-Medication Contents; World Health Organization: Geneva, Switzerland, 1998.

42. World Health Organization. WHO Collaborating Centre for Drug Statistics Methodology, Guidelines for ATC Classification and DDD Assignment; World Health Organization: Geneva, Switzerland, 2015.

43. Kennedy-Dixon, T.-G.; Gossell-Williams, M.; Hall, J.; Anglin-Brown, B. The prevalence of major potential drug-drug interactions at a University health centre pharmacy in Jamaica. Pharm. Pr. 2015, 13, 601. [CrossRef] [PubMed]

44. American Diabetes Association 9. Pharmacologic Approaches to Glycemic Treatment: Standards of Medical Care in Diabetes-2020. Diabetes Care 2020, 43, S98-S110. [CrossRef] [PubMed]

45. Wang, J.; Ciaraldi, T.P.; Samad, A.M. Tissue Factor Expression in Obese Type 2 Diabetic Subjects and Its Regulation by Antidiabetic Agents. J. Obes. 2015, 2015, 1-8. [CrossRef] [PubMed]

46. Schweitzer, M.L.; Stengel, B.; Legrand, K.; Briançon, S.; Jacquelinet, C.; Combe, C.; Fouque, D.; Massy, Z.A.; Laville, M.; Frimat, L.; et al. Obesity phenotype and patient-reported outcomes in moderate and severe chronic kidney disease: A cross-sectional study from the CKD-REIN cohort study. Qual. Life Res. 2019, 28, 1873-1883. [CrossRef] [PubMed] 
47. Al Hamid, A.; Ghaleb, M.; Aljadhey, H.; Aslanpour, Z. A systematic review of qualitative research on the contributory factors leading to medicine-related problems from the perspectives of adult patients with cardiovascular diseases and diabetes mellitus. BMJ Open 2014, 4, e005992. [CrossRef] [PubMed]

48. Ikäheimo, I.; Karjalainen, M.; Tiihonen, M.; Haanpää, M.; Kautiainen, H.; Saltevo, J.; Mäntyselkä, P. Clinically relevant drug-drug interactions and the risk for drug adverse effects among home-dwelling older persons with and without type 2 diabetes. J. Clin. Pharm. Ther. 2019, 44, 735-741. [CrossRef]

49. Saastamoinen, L.K.; Verho, J. Register-based indicators for potentially inappropriate medication in high-cost patients with excessive polypharmacy. Pharmacoepidemiol. Drug Saf. 2015, 24, 610-618. [CrossRef] [PubMed]

50. Maideen, N.M.P.; Jumale, A.; Balasubramaniam, R. Drug Interactions of Metformin Involving Drug Transporter Proteins. Adv. Pharm. Bull. 2017, 7, 501-505. [CrossRef] [PubMed]

51. Kalafutova, S.; Juraskova, B.; Vlcek, J. The impact of combinations of non-steroidal anti-inflamatory and anti-hypertensive agents on blood-pressure. Adv. Clin. Exp. Med. 2014, 23, 993-1000. [CrossRef] [PubMed]

52. Fournier, J.P.; Lapeyre-Mestre, M.; Sommet, A.; Dupouy, J.; Poutrain, J.C.; Montastruc, J.L. Laboratory monitoring of patients treated with antihypertensive drugs and newly exposed to nonsteroidal anti-inflammatory drugs: A cohort study. PLoS ONE 2012, 7, 1-6. [CrossRef]

53. Srinivasan, A.; De Cruz, P. Review article: A practical approach to the clinical management of NSAID enteropathy. Scand. J. Gastroenterol. 2017, 52, 941-947. [CrossRef]

Publisher's Note: MDPI stays neutral with regard to jurisdictional claims in published maps and institutional affiliations. 